\title{
Governing Well after War: How Improving Female Representation Prolongs Post-conflict Peace
}

\author{
Sarah Shair-Rosenfield, Arizona State University \\ Reed M. Wood, Arizona State University
}

Previous studies suggest that women's access to political power often increases following the termination of civil conflicts, particularly those ending in negotiated settlement. However, the effect of these changes has received limited attention. We argue that the proportion of female representatives in a national legislature prolongs peace following a negotiated settlement. Moreover, we highlight two mechanisms through which greater female representation reduces the risk of conflict recurrence: (1) by prioritizing social welfare spending over military spending and (2) by improving public perceptions of good governance and the credibility of political elites. We further argue that legislative independence and authority conditions this relationship, implying that greater female representation is more likely to promote peace in states with nominally democratic political institutions. Our empirical analyses of peace duration following negotiated settlements between 1946 and 2011 provide robust support for our general argument and the underlying mechanisms we believe drive this relationship.

If women were fully engaged in all these aspects of peacebuilding, they would help prevent the impunity that undermines efforts to re-establish the rule of law.... In governance, if women were engaged in policy decision making and employed in public administration, we would see more diversity expressed in policy making and more attention to community and family needs. ${ }^{1}$

—Michelle Bachelet, Chilean president and former executive director of UN Women

G ender inclusivity - particularly the incorporation of women into both peace processes and post-conflict political decision making - has been promoted by the international community through measures such as UN Security Council Resolution (UNSCR) 1325 and implemented in various ways in many states at risk of, or emerging from, instability and violence. ${ }^{2}$ Through such mechanisms, the United Nations and its member states have highlighted the disproportionate impact of war on the lives of women and called attention to the important roles women can play in conflict resolution and the maintenance of peace. As the above statement from Michelle Bachelet emphasizes, the rationale behind UNSCR 1325 implicitly asserts that peace is more frag- ile when women, their perspectives, and their preferences are excluded from the political process and from political decision making.

Previous studies demonstrate that women's status in society plays an important role in the production and resolution of political violence (e.g., Hudson et al. 2009) and that women's access to political power often increases following the termination of violent civil conflict (e.g., Hughes and Tripp 2015). Yet, few studies have directly examined the influence of increasing gender diversity within national political intuitions on peace and conflict processes. ${ }^{3}$ Here, we consider the potential influence of greater incorporation of women in national legislatures on the duration of peace in states emerg-

Sarah Shair-Rosenfield (Sarah.shair-rosenfield@asu.edu) is assistant professor in the School of Politics and Global Studies at Arizona State University, Tempe, AZ 85287-3902. Reed M. Wood (Reed.Wood@asu.edu) is associate professor in the School of Politics and Global Studies at Arizona State University, Tempe, AZ 85287-3902.

Data and supporting materials necessary to reproduce the numerical results in the paper are available in the JOP Dataverse (https://dataverse .harvard.edu/dataverse/jop). An online appendix with supplementary material is available at http://dx.doi.org/10.1086/691056.

1. "Greeting to the World Peace Festival, August 20-27, 2011, Berlin, Germany." https://www.youtube.com/watch?v=zh0lcNJmLQ0\&index $=19 \&$ list =PLxWil8G-73_J5d-tvX3I-vaNfJemwjR_I (accessed April 25, 2017).

2. While recognizing the distinction between gender (as a social construct) and sex, we follow existing studies in the literature on "politics and gender" and use the term "gender" to refer to biological gender, which reflects the physical attributes of an individual at birth.

3. For a review of the literature on the positivist study of women and conflict, see Reiter (2015).

The Journal of Politics, volume 79, number 3. Published online May 11, 2017. http://dx.doi.org/10.1086/691056 
ing from violent civil conflict. States emerging from such conflicts - particularly those terminating in a negotiated settlement-face a persistent risk of conflict relapse. Large-scale internal conflict produces grievances, underdevelopment, and mistrust among recent adversaries, which in turn raises the risk of future episodes of violence (Collier et al. 2003; Walter 2014). Breaking this "conflict trap" necessitates interventions that can effectively address the underlying conditions that drive this cycle. As we argue below, increasing female representation within national legislatures represents one potentially fruitful intervention to increase peace durability.

In contrast to previous studies addressing related questions (e.g., Demeritt, Nichols, and Kelly 2015; Ruddick 1995), we make no assumptions regarding women's inherent pacifistic attitudes per se. Similarly, while acknowledging the important role that societal gender norms play in shaping the risk of violent conflict (Caprioli 2005; Hudson et al. 2009; Melander 2005), we place female political elites at the forefront of the argument by identifying and recognizing their potential agency in peace processes. In brief, we argue that legislatures with larger proportions of female representatives positively influence the durability of peace through two mechanisms: (1) by prioritizing social welfare spending over military spending and (2) by positively influencing public perceptions of governance quality and elite credibility. In building our argument, we rely on literature linking good governance to state stability and the duration of post-conflict peace, as well as studies highlighting gender-based differences in policy preferences and public perceptions of female elites. We also consider the conditioning impact of a post-conflict state's political institutions on the relationship between female representation and peace durability. Specifically, legislatures exert greater influence over policy and are typically perceived to be more credible in states with nominally democratic formal political institutions. Consequently, we expect that the influence of female representation on peace durability is strongest in more democratic states because it is under these conditions that female legislators are more likely to shape policy and influence public perceptions.

We examine the validity of our argument using crossnational data on the proportion of women in national legislative bodies and the duration of peace following civil conflicts terminated via negotiated settlement between 1946 and 2011. The results of our empirical analysis provide strong support for our central argument: rising female representation rates increase the durability of peace following conflicts terminated via negotiated settlements, especially in states with more democratic political institutions. These results are robust to a variety of alternative specifications. Furthermore, we also find evidence of the mechanisms that we believe drive this relationship: increased female representation influences public spending patterns in post-conflict states and improves the perceived quality of governance and elite credibility, which in turn reduce the odds of conflict recurrence. Consequently, our findings support the argument that increasing female representation may help promote durable peace following negotiated settlements to civil conflict.

\section{GENDER AND ARMED CONFLICT}

Several existing studies have examined the influence of gender and gender norms on support for, and involvement in, violent conflict. One body of research asserts that, either as a result of biology or socialization, women are generally more pacifistic than men and inherently resistant to war and militarism (e.g., Ruddick 1995). Later studies have used this assertion to argue that peace becomes more likely where women are better integrated into a state's political and social institutions (Demeritt et al. 2015). However, much of the recent literature examining the relationship between gender and conflict asserts that, like men, women are capable of either perpetrating violence or promoting peace (e.g., Sjoberg and Gentry 2007). While this observation does not rule out the possibility that gender inclusivity in social and political institutions promotes peace, it suggests that any theoretical links between gender and peace should be rooted in claims other than the innate peacefulness of women.

An alternative strand of research largely eschews any connection between women's preferences regarding violence and conflict prevalence and instead highlights the central role that broader social gender dynamics and norms play in the onset or perpetuation of political violence. This research suggests that the existence of patriarchal structures and gender-based inequality within society exerts a profound impact on a state's propensity for political and social violence (Caprioli 2005; Hudson et al. 2009; Melander 2005). Yet, while gender norms may represent a key explanation for social and political violence propensity, they reflect slow-moving societal transformations that occur over decades. As such, they are unable to explain variation in violence over relatively short time horizons. In addition, these studies often overlook the potential agency of an important subgroup of actors and appear to disregard literature highlighting gender-based differences in policy preferences, including attitudes toward the use of violence (Brooks and Valentino 2011; Conover and Sapiro 1993; McDermott and Cowden 2002).

A handful of recent studies have acknowledged the potential contributions of women (as a distinct group) to securing peace when they are integrated into policy-making and political processes. For example, Caprioli, Nielsen, and Hudson (2010) find that post-conflict peace is more durable when women directly participate in the peace process. According 
to Koch and Fulton's (2011) analysis of established democracies, states with greater numbers of female legislators are less likely to become involved in international armed conflicts, and they spend less on national defense. Finally, Demeritt et al. (2015) find that increasing the inclusion of women in social and political institutions reduces the risk of civil war recurrence.

We take these studies as our point of departure. Our approach focuses on the potential influence of female legislators on the likelihood of violence, and we apply our argument to the durability of peace in states emerging from violent internal conflicts terminated via negotiated settlement. By focusing on such cases, we can better isolate the influence of changes in political leadership as distinct from the influence of underlying societal factors such as gender norms. Furthermore, we do not make assumptions about women's inherent peacefulness and instead focus on differences in the policy priorities and public perceptions of male and female legislators that have been empirically documented elsewhere. As we elaborate in more detail below, these differences - or rather the outcomes they produce-represent the mechanisms driving the anticipated relationship between female representation and conflict recurrence.

\section{NEGOTIATED SETTLEMENTS AND FEMALE REPRESENTATION}

While our argument centers on the impact of female representation on peace durability, we first discuss the relationship between the termination of civil conflict and subsequent patterns of female representation. Previous studies demonstrate that the termination of a civil conflict often contributes to an increase in the rate of female representation (Hughes 2009; Hughes and Tripp 2015; Tripp 2015). These studies contend that the growth in women's representation following conflict termination results from both changes in the post-conflict state's political institutions and international efforts to increase women's presence within domestic political institutions.

While war termination often creates new opportunities for women to participate in political decision making, these opportunities are most likely to occur in the context of negotiated settlement. Negotiated settlements often lead to the development and implementation of new governance structures, electoral systems, and laws (particularly in the case of powersharing agreements), which often dramatically expand the population eligible to participate in policy making and politics (e.g., Hartzell, Hoddie, and Rothchild 2001). More specifically, external actors involved in peace negotiations, peacekeeping missions, and the provision of post-conflict aid often encourage and incentivize states to introduce affirmative action mechanisms, such as gender quotas, that positively in- fluence female political representation rates (Anderson and Swiss 2014; Bush 2011). Organizations such as the UN Development Fund for Women (UNIFEM), which provide significant resources to post-conflict states, have focused increasing attention on gender equality and the promotion of gender balance (Krook and True 2012; Paxton, Hughes, and Green 2006).

In addition, the inclusion of domestic civil society in the peace process - particularly women's organizations influenced and emboldened by contact with international actors - helps contribute to increasing women's political representation following a peace agreement (Hughes and Tripp 2015, 1531). Ties between domestic civil society groups and transnational women's organizations are capable of bringing women into the peace process and post-conflict political institutions even when warring parties have largely sidelined women (Ellerby 2013; Paffenholz 2014). Consequently, because negotiations often involve actors interested in promoting women's rights and political access, they are more likely to create opportunities for women's inclusion in political decision making relative to conflicts that terminate via other means.

Table 1 illustrates the relationship between the way in which a conflict terminated and the gender balance in state legislatures for the years 1946-2011. Data on post-conflict periods and methods of termination come from the UCDP/ PRIO Armed Conflict Dataset (ACD) (v.4) and UCDP Conflict Termination Dataset (v.2) (Gleditsch et al. 2002; Kreutz 2010). Data on female representation are from the Women in Parliament Dataset (Paxton, Green, and Hughes 2008). The data demonstrate that five years prior to conflict termination, there is little difference between the rates of female representation in cases of conflict termination via negotiated settlement and cases where the conflict terminated via other

Table 1. Female Representation Rates in Post-conflict States

\begin{tabular}{cccc}
\hline & $\begin{array}{c}\text { Negotiated } \\
\text { Settlement }\end{array}$ & $\begin{array}{c}\text { No Negotiated } \\
\text { Settlement }\end{array}$ & Difference \\
\hline $\begin{array}{c}\text { years prior to } \\
\text { termination }\end{array}$ & 6.84 & 6.75 & -.08 \\
$\begin{array}{c}\text { Year of } \\
\text { termination }\end{array}$ & 7.92 & 7.38 & -.54 \\
5 years post- \\
termination
\end{tabular}

Note. Difference reflects the difference in representation rates across types of cases at specified time point.

${ }^{*} p \leq .05$ in difference of means test between termination types at 5 years post-conflict. 
means. ${ }^{4}$ While the percentage of female representatives in the legislature increases slightly in both groups at the point of conflict termination, the difference between negotiated settlement cases and other cases remains minimal. However, the differences become apparent in the years following the conflict. At five years post-conflict, female representation in cases terminated via negotiated settlement increases $45 \%$ compared to five years prior to termination. By contrast, representation rates only increase by $12 \%$ among states where the conflict terminated via other means over the same window of time. Consistent with the literature discussed above, this suggests that conflict termination via negotiated settlement is often an intervention that increases female representation in national legislatures. Moreover, these data suggest that the mode of conflict termination influences post-conflict female representation rates rather than female representation shaping the likelihood of settlement. This observation is important because it reduces concerns about potential selection issues that might bias any observed empirical relationship between female representation rates and peace durability.

\section{FEMALE REPRESENTATION AND DURABLE PEACE}

We now turn to our central argument, which focuses on the potentially positive influence of increasing female representation on the ability of states to break free from the "conflict trap" and secure durable post-conflict peace. States emerging from civil wars are disproportionately likely to relapse into conflict, perpetuating a cycle of poverty, poor governance, and conflict (Collier et al. 2003). The efficient and effective allocation of state resources to rebuilding infrastructure destroyed during the conflict and meeting the welfare needs of the population represent a key to promoting stability and reducing the risk of conflict recurrence. Relatedly, convincing the population that the new government possesses both the capability and interest to adequately address these issues also shapes the odds of post-conflict peace. Specifically, when perceptions of elite credibility are low and the public maintains a poor opinion of the quality of governance provided by the new government, the risk of return to conflict increases. Governments that can address the needs of the population and promote perceptions of good governance among their citizens are less likely to face renewed challenges to their authority. Particularly following a negotiated settlement, preserving the fragile peace necessitates sustained negotiation and compromise among previous warring parties. By contrast, conflicts ending in decisive victory for one side are less likely to recur because one side has been effectively vanquished, limiting its

4. We compare termination via ceasefire or peace agreement to termination via decisive victory or "low-intensity." ability to mount a renewed challenge to its adversaries and signaling the likely fate of other challengers. It is for these reasons that previous studies find that wars terminating in stalemates or negotiated settlements are more likely to recur compared to those ending in decisive victories (e.g., Toft 2009; Walter 2014, 21).

While often overlooked in previous studies of conflict recurrence, civilian attitudes exert a significant influence on strategies that former militant leaders adopt (Mukherjee 2006). Specifically, the level of support insurgent leaders expect to receive from their civilian constituents (including demobilized former troops) is central to their willingness and ability to renege on a settlement and revive the conflict. Indeed, governments explicitly attempt to shape the attitudes of rebels' civilian constituents in order to minimize rebel leaders' ability to draw on this population for support if there is a resumption of violence $(484,489)$. The provision of public goods and signals of effective governance represent two ways in which the government can increase public loyalty and potentially weaken loyalty to former insurgent leaders, subsequently reducing the risk of war recurrence.

Moreover, factors that positively influence these perceptions should increase the prospects for securing durable peace. In this section, we argue that legislatures with larger proportions of female representatives influence the durability of peace by shaping state spending priorities and alter the odds of conflict recurrence by positively influencing public perceptions of governance quality and elite credibility. To be clear, we are not arguing that increasing female representation represents the only - or even the most common-means of prioritizing social welfare spending and improving perceptions of governance quality. However, several existing studies suggest that increasing the rate of female representation may positively influence these factors, thus influencing the durability of post-conflict peace.

\section{Spending priorities}

The ability to devote scarce state resources to public (rather than private) goods and the implementation of effective development policies is often an essential component of creating durable peace (Collier et al. 2003; Murshed 2002). Yet, rather than devoting state resources to implementing policies that address popular grievances, state leaders often maintain high levels of spending on the security sector because the perceived risk of conflict relapse causes pressures to maintain military readiness (Collier and Hoeffler 2006, 90; Ghobarah, Huth, and Russet 2004; Iqbal 2010, 124-25). Patterns of resource scarcity and underdevelopment that drove the previous conflict may therefore remain unaddressed (or worsen) as the new government diverts financial resources away from 
infrastructure or social welfare projects that could positively influence peace and stability. States that maintain high levels of military spending at the expense of social spending are therefore more likely to experience conflict recurrence (Collier et al. 2003, 71-72, 184). Similarly, Azam (2001) asserts that a state's failure to credibly devote substantial resources to redistribution and social welfare increases the odds that it experiences social and political violence. Recent empirical studies investigating this relationship also find that states that devote greater resources to the provision of social welfare reduce the risk of violent internal conflict by improving living standards, enhancing social stability, and reducing incentives for violent mobilization against the state (Taydas and Peksen 2012; Thyne 2006). In short, it appears that a state's spending priorities influence its risk of experiencing civil conflict.

Changes in post-conflict spending priorities represent one of the central mechanisms through which we believe that rising female representation rates reduce the risk of conflict recurrence. Specifically, increasing female legislative representation - in the body typically charged with the allocation of state resources - is likely to influence spending priorities, thereby indirectly influencing the likelihood of conflict recurrence. Existing studies demonstrate that female legislators pursue different policies than their male counterparts and can successfully shape policy outputs that reflect these interests as their proportion of seats grows. ${ }^{5}$ For instance, states with larger proportions of female legislators tend to provide greater amounts of foreign aid to states experiencing humanitarian disasters (Hicks, Hicks, and Maldonado 2015). Furthermore, legislative bodies with greater numbers of women are both more likely to produce legislation that addresses development, social welfare, and social justice issues (Carroll 2001; Kittilson 2008; Lu and Breuning 2014) and to increase social welfare expenditures (Bolzendahl and Brooks 2007). Similarly, developing states with larger proportions of female legislators are more likely to demonstrate improvements in key indicators of social welfare (Swiss, Fallon, and Burgos 2012). They are also more likely to focus their attention on priorities most directly affecting women's lives: women are disproportionately their families' primary caregivers, disproportionately employed in social welfare sectors such as healthcare and education, and typically less directly benefited by military spending.

As such, women legislators are more likely to spend on social welfare due to holding feminist preferences (Carroll

5. Notably, previous studies suggest that even small increases in women's descriptive representation may exert a substantive impact on policy outcomes (e.g., Crowley 2004; Erickson 1997).
2001) and/or having shared life experience that leads them to acutely value such spending (Mansbridge 1999). For example, in 1999, South African female legislators protested expanding military expenditures at the expense of spending on economic development and healthcare (Anderlini 2007, 142). Three years later, Parliamentarian Pregs Govender resigned in protest over the government's continued increases in military spending, stating, emphatically, " 24,000 people die every day from poverty, and women and children continue to bear the brunt of this.... War makes the profit margins that peace does not. We have to loudly say No! No! No! We will not accept that human life is so easily devalued and dispensable" (Govender 2002). Govender's efforts to resist increased military spending at the expense of allocations for social welfare programs may illustrate a more general empirical trend. While few existing studies have directly assessed the relationship between female representation rates and the tradeoff between military and social spending, Koch and Fulton (2011) find that among democratic states, military spending declines as the proportion of female legislators increases.

Both the anecdotal evidence and recent empirical analyses discussed above suggest that female policy makers are often acutely aware of the implications of the trade-off between "guns and butter" and are more likely than their male counterparts to prioritize the latter. Thus, higher rates of female representation in national legislatures should contribute to greater social welfare expenditures. This does not necessarily imply that female political elites are inherently more pacifistic; rather, it suggests that female leaders may view human security through a different lens than their male counterparts. To the extent that increasing female representation shapes spending priorities, it should therefore also have an impact on the likelihood of civil conflict recurrence.

\section{Perceptions of governance quality and elite credibility}

Perceptions of governance quality, the credibility of elites and policy makers, and overall trust in the new government represent the second set of mechanisms through which we argue that female legislative representation influences the durability of peace. Walter (2014), for example, demonstrates that the presence of institutions that signal accountability and elite commitment to the terms of a negotiated settlement exert a powerful suppressive influence on conflict recurrence. Consistent with this perspective, several recent studies find that variables accounting for the quality and perceptions of quality of governance-including government effectiveness, social spending, and corruption controls - reduce the risk of conflict recurrence (Cammett and Malesky 2012; Fearon 2011; Hegre 
and Nygärd 2015). In a similar manner, numerous studies highlight the importance of elite credibility and inter-elite trust in preserving post-conflict peace. Indeed, power-sharing mechanisms and institutions that promote good governance are expected to help promote peace where trust is low and doubts regarding actors' credibility remain high (Hartzell and Hoddie 2007; Hartzell et al. 2001; Mattes and Savun 2009). Greater inclusivity may promote cooperation and perceptions of credibility by signaling a break from the political status quo.

As we noted above, conflict termination creates new opportunities for women to participate in political decision making and tends to increase female representation rates. Given that states that are most likely to experience internal conflicts also tend to exclude women from positions of political authority (Melander 2005), increases in the rate of female representation following conflict suggest the introduction of "new faces" into positions of power. Political newcomers are more likely to represent a break with the past and less likely to be viewed as responsible for past political failures and the traumas inflicted on the population during the war. In other words, the replacement of the "old guard" with new political actors signals new opportunities for cooperation and may positively influence public perceptions of the quality of governance in the post-conflict state.

The effect of elite turnover on public perceptions of trust and credibility may be most direct when the new elites are women. Previous research demonstrates that both women and men perceive women as more peaceful than men (Rudman and Goodwin 2004). Whether or not women are actually more committed to peace is largely irrelevant in this context; what matters is that audiences perceive that female elites are more likely to choose policies conducive to peace over those conducive to war. Koch and Fulton $(2011,4)$ similarly note that cross-national research on gender stereotypes finds that audiences perceive that women are generally more cooperative and compassionate. Moreover, audiences generally perceive female candidates and policy makers to be comparatively less corrupt than men (Barnes and Beaulieu 2014; Treisman 2007), more dedicated to earnest and honest governance (McDermott 1998), and more committed to compromise (Pew Research Center 2015, 6). Previous studies also demonstrate a positive correlation between women's legislative representation and trust in Congress in the United States and Latin America (Lawless 2004; Schwindt-Bayer 2010). Anecdotal evidence further suggests that citizens in post-conflict states often view female politicians as less corrupt and more dedicated to providing public goods (McGrew, Frieson, and Chan 2004). In sum, the perception - if not the reality - that women are more trustworthy than their male counterparts is well established in the existing literature.
The literature reviewed above suggests that increasing the number of female decision makers should positively influence public perceptions that newly included elites are less encumbered by previous political disputes, more credible, and more likely to govern effectively. Ultimately, as the perceived credibility of the government and the perception of leaders' commitment to good governance increases, popular support for a return to violent rebellion against the state should decline. In other words, these factors should diminish the potential support militant leaders expect from their civilian supporters, thus reducing their incentives to draw the country back into conflict.

\section{Summary and hypotheses}

Previous studies highlight the fragility of peace following negotiated settlement in contrast to conflicts terminating via other means. In part, the high risk of conflict recurrence endures because the regime often prioritizes security interests over social welfare interests, thus failing to address the factors that motivated or enabled the conflict in the first place. Breaking this conflict trap therefore requires altering spending priorities. Relatedly, perceptions of the quality of governance and belief in elites' commitment to peace influence the risk of conflict recurrence. Where trust remains low and audiences perceive that the government is ineffective, unaccountable, and corrupt, incentives for violence will linger among the population, particularly among former combatants. We argue, however, that increasing female representation in national legislative bodies can improve the prospects of such outcomes and contribute to the prevention of conflict recurrence. Particularly, we assert that female legislative representation influences peace durability following negotiated settlements by altering spending priorities and improving public perceptions of the quality of governance. This produces our central hypothesis:

H1. Following a negotiated settlement, states with a greater proportion of female representatives in the national legislature are less likely to experience conflict relapse.

The above discussion suggests a general relationship between female representation in legislatures and peace durability. However, the argument rests in part on the assumption that these legislators have the ability to influence policies or that they are at least perceived to possess such influence. While previous research suggests that legislative bodies in authoritarian and other undemocratic systems can restrain state leaders and successfully shape policy outputs (e.g., 
Gandhi 2008), legislative influence and authority are typically greater in democratic states. Consequently, the mechanisms we propose should exert a stronger influence in states with more democratic institutions compared to more autocratic states. In other words, the influence of female legislators to affect policy is likely most constrained under conditions of weak legislative authority, while female legislators are most efficacious in more democratic systems. Similarly, we expect the public to perceive democratic legislatures as comparatively more effective and to view their members' promises to deliver desired policies as more credible. Thus, we anticipate that the relationship between female representation and peace durability is conditioned by a state's prevailing political institutions. This produces our second hypothesis:

H2. The influence of female representation on the risk of conflict recurrence following civil conflict increases in the context of more democratic political institutions.

\section{RESEARCH DESIGN AND EMPIRICAL ANALYSES}

Our argument posits that states with higher female representation rates in the national legislature are less likely to experience civil conflict recurrence following a negotiated settlement compared to states whose legislative bodies remain more male-dominated. Our argument linking female representation and peace durability following a negotiated settlement focused on two specific mechanisms: national legislatures implementing policies that effectively address the grievances that likely prompted and sustained the initial conflict and public perceptions of good governance and elite credibility. While our primary intention is to demonstrate the relationship between female representation rates and the durability of peace, we first endeavor to demonstrate the validity of our proposed mechanisms. We then turn to our primary analysis, which examines the influence of female representation rates - as well as state spending priorities and perceptions of governance qualityon the durability of peace following negotiated settlement.

\section{Female representation, spending, and governance quality}

We begin with an examination of the relationship between the rate of female representation in post-conflict legislatures and measures of government spending priorities and perceptions of the quality of governance. To do so, we first identify a sample of post-conflict cases. We base our sample on the cases of intrastate and internationalized internal armed conflicts included in the UCDP/PRIO Armed Conflict Dataset (ACD) (v.4) (Gleditsch et al. 2002). For inclusion in this data set, a conflict must center on a stated incompatibility (territorial or governmental) between the host state government and an armed adversary that results in at least 25 battle-related deaths per year. Because lower-intensity conflicts frequently terminate and re-emerge, making it difficult to determine precise end dates, we adopt the commonly employed practice of merging conflict episodes separated by fewer than two years into the same episode. A conflict is coded as terminated when it produces fewer than 25 battle-related deaths each year for two consecutive years. Similarly, conflict recurrence is coded when violence exceeds 25 deaths in a year after at least a twoyear lull in the fighting. Because our argument about the influence of female representation is most theoretically pertinent in post-conflict periods following negotiated settlement, we limit our analysis to these cases. Specifically, our sample includes only conflicts coded as terminating via formal peace agreements or ceasefires according to the UCDP Conflict Termination Dataset (v.2) (Kreutz 2010). Peace periods therefore reflect all years between the termination of a given conflict via a negotiated settlement and its recurrence. After accounting for differences in the temporal window for some of the covariates included in the analysis, our sample represents 58 distinct conflicts occurring in 48 countries between 1946 and 2011.

Our primary explanatory variable is the rate of Female Representation. We follow existing studies and include only the proportion of women sitting in the lower (or only) chamber of a state's national legislature during the year. This is a common practice since most upper chambers lack significant political authority due to partisan congruence with the lower chamber and/or because the lower chamber is vested with much greater power over budgets and policy making (Lijphart 1987). Consequently, this coding captures the proportion of women in the body that is most likely to influence the mechanisms highlighted above. Data for this variable come primarily from the Women in Parliament Dataset (Paxton et al. 2008), but this is supplemented with information from the World Bank's World Development Indicators (WDI) Database (World Bank 2015). ${ }^{6}$

We rely on multiple measures to capture state spending priorities and perceptions of governance quality. First, we construct the variable Spending Ratio, which reflects the

6. Every country in our post-World War II sample possesses some form of national legislative body at some point during the sample window. During years in which no legislature existed or where it was (temporarily) suspended, we code these cases as missing. However, we recode Female Representation as 0 for these observations and include a dummy variable reflecting the presence or absence of a legislature during the year in the analysis. The results are similar (see the appendix). 
spending priorities of the national government. To generate the indicator, we divide total annual health expenditures by military expenditures to create a ratio in which larger values reflect greater spending on health relative to the military. We log-transform this ratio measure because of its significant positive skew. These data are taken from the United Nations' data website (United Nations 2016b) and the WDI, respectively. We rely on three variables from the World WGI database as proxies for perceptions of government credibility (Kaufmann, Kraay, and Mastruzzi 2011).? Accountability captures perceptions of the extent to which citizens are able to participate in the selection of their government and to engage in free political expression. Effectiveness reflects perceptions of the quality of public services, the perceived freedom of the civil service from political control, and the government's commitment to high quality policy formulation and implementation. Finally, Corruption Control reflects perceptions of the extent to which political elites exercise public power for private gains, as well as perceptions of the "capture" of the state by elites and private interests. While none of these variables completely captures attitudes toward political elites, trust in government, or a belief in elites' commitment to peace, they should serve as adequate proxies for these concepts. Importantly, they should represent a reasonable test of our arguments because they explicitly capture perceptions of the quality of governance in a state rather than institutions or laws. The creators generate each indicator by combining multiple individual data sources (e.g., citizen, expert, and enterprise surveys) through a statistical tool known as an Unobserved Components Model. ${ }^{8}$ Each resulting indicator is a standardized, normally distributed continuous measure ranging from -2.5 to 2.5 .

We include several relevant controls in all of our models of spending and governance quality. We first control for the state's formal political institutions with an indicator representing institutional Democracy. We rely on the 21-point Polity 2 measure of the Polity IV data set (Marshall, Jaggers, and Gurr 2011). To test our second hypothesis, we interact Democracy with Female Representation. We control for Wealth by including estimated GDP per capita as well as the size of the state's Population (Gleditsch 2002, updated through 2011). We also control for the duration of the previous conflict with the variable Conflict Duration and the time since the last conflict with the variable Years Since Conflict. We

7. The WGI measures are available only every other year between 1996 and 2001 and every year thereafter. For our analyses, we linearly interpolate the missing years.

8. For detailed information on the methodology, see Kaufmann et al. (2011). include the variables Natural Resource Revenue and Foreign Aid, both as percentages of GDP (gross domestic product), because they often serve as sources of elite rent-seeking, which can erode governance quality. These data come from the WDI (World Bank 2015).

Several previous studies also highlight the important role that Power Sharing institutions play in preventing conflict recurrence following negotiated settlement. In part, such agreements may promote beneficial spending policies, encourage trust among elites, and improve citizens' perceptions of governance quality. We therefore include a binary indicator accounting for the presence of such institutions (Cammett and Malesky 2012; Hartzell and Hoddie 2007). Finally, we control for the presence of an Active Conflict in the county. States may be subject to multiple civil conflicts, and the emergence of a new conflict may lead to an increase in military spending and de-prioritization of social welfare spending. It may also erode public perceptions of good governance. This variable is coded 1 if the UCDP/PRIO ACD data set indicates that a state was host to any additional conflicts (not associated with the previously terminated conflict) during a given year.

We report the results of our spending and governance models in table 2. In all models, we lag Female Representation to account for the time lag between legislative decision making and policy outcomes. ${ }^{9}$ In the interest of space, we only discuss these results in brief. We note that the Female Representation rate exerts a positive and statistically significant influence on both the spending variable and on the proxies for public perceptions of governance quality, except in the case of Effectiveness, where the coefficient is positive but fails to achieve statistical significance. The Female Representation $\times$ Democracy interaction term also exerts a positive and statistically significant influence on these outcomes, except in the case of Accountability, where the coefficient is positive but fails to achieve statistical significance. Overall, these results suggest that legislatures with larger proportions of female members spend comparatively more on social welfare expenditures relative to military expenditures when compared to legislatures with fewer women, particularly in countries with democratic political institutions. We observe a similar relationship between female representation and our measures of the perception of good governance. These results do not necessarily imply that governments with greater proportions of women are in fact more effective and accountable or less corrupt. Rather, the results suggest

9. The spending data and WGI measures are available from 1995 and 1996, respectively, thus limiting the time frame of our analysis and substantially reducing the number of observations. 
Table 2. Determinants of Spending and Good Governance

\begin{tabular}{|c|c|c|c|c|c|c|c|c|}
\hline & \multicolumn{2}{|c|}{ Spending } & \multicolumn{2}{|c|}{ Accountability } & \multicolumn{2}{|c|}{ Effectiveness } & \multicolumn{2}{|c|}{ Corruption Control } \\
\hline & Model 1 & Model 2 & Model 3 & Model 4 & Model 5 & Model 6 & Model 7 & Model 8 \\
\hline Female representation $_{(t-1)}$ & $\begin{array}{c}.009^{\star} \\
(.004)\end{array}$ & $\begin{array}{r}-.004 \\
(.006)\end{array}$ & $\begin{array}{c}.004^{*} \\
(.002)\end{array}$ & $\begin{array}{c}.002 \\
(.003)\end{array}$ & $\begin{array}{c}.003 \\
(.002)\end{array}$ & $\begin{array}{r}-.002 \\
(.003)\end{array}$ & $\begin{array}{c}.006^{*} \\
(.002)\end{array}$ & $\begin{array}{r}-.000 \\
(.003)\end{array}$ \\
\hline Democracy & $\begin{array}{c}.030^{*} \\
(.008)\end{array}$ & $\begin{array}{c}.009 \\
(.011)\end{array}$ & $\begin{array}{c}.057^{\star} \\
(.005)\end{array}$ & $\begin{array}{c}.053^{*} \\
(.007)\end{array}$ & $\begin{array}{c}.010^{*} \\
(.003)\end{array}$ & $\begin{array}{c}.001 \\
(.004)\end{array}$ & $\begin{array}{c}.010^{*} \\
(.004)\end{array}$ & $\begin{array}{r}-.002 \\
(.005)\end{array}$ \\
\hline Wealth (natural log) & $\begin{array}{r}-.205^{\star} \\
(.056)\end{array}$ & $\begin{array}{r}-.229^{\star} \\
(.055)\end{array}$ & $\begin{array}{c}.129^{*} \\
(.030)\end{array}$ & $\begin{array}{c}.126^{\star} \\
(.030)\end{array}$ & $\begin{array}{c}.275^{\star} \\
(.027)\end{array}$ & $\begin{array}{c}.270^{*} \\
(.026)\end{array}$ & $\begin{array}{c}.144^{*} \\
(.024)\end{array}$ & $\begin{array}{c}.137^{\star} \\
(.025)\end{array}$ \\
\hline Population (natural log) & $\begin{array}{c}.135^{*} \\
(.063)\end{array}$ & $\begin{array}{c}.168^{*} \\
(.062)\end{array}$ & $\begin{array}{r}-.098^{*} \\
(.034)\end{array}$ & $\begin{array}{r}-.096^{*} \\
(.034)\end{array}$ & $\begin{array}{r}-.210^{*} \\
(.030)\end{array}$ & $\begin{array}{r}-.204^{*} \\
(.030)\end{array}$ & $\begin{array}{r}-.166^{*} \\
(.029)\end{array}$ & $\begin{array}{r}-.156^{*} \\
(.029)\end{array}$ \\
\hline Conflict duration (natural log) & $\begin{array}{c}.002 \\
(.026)\end{array}$ & $\begin{array}{c}-.003 \\
(.026)\end{array}$ & $\begin{array}{c}.001 \\
(.010)\end{array}$ & $\begin{array}{c}.001 \\
(.010)\end{array}$ & $\begin{array}{r}-.008 \\
(.013)\end{array}$ & $\begin{array}{c}-.009 \\
(.012)\end{array}$ & $\begin{array}{c}.002 \\
(.012)\end{array}$ & $\begin{array}{c}.001 \\
(.012)\end{array}$ \\
\hline Time since conflict (natural log) & $\begin{array}{c}.026 \\
(.022)\end{array}$ & $\begin{array}{c}.033 \\
(.022)\end{array}$ & $\begin{array}{c}.030^{\star} \\
(.012)\end{array}$ & $\begin{array}{c}.032^{\star} \\
(.012)\end{array}$ & $\begin{array}{c}.015^{*} \\
(.009)\end{array}$ & $\begin{array}{c}.017^{\star} \\
(.009)\end{array}$ & $\begin{array}{c}.006 \\
(.009)\end{array}$ & $\begin{array}{c}.009 \\
(.010)\end{array}$ \\
\hline Power sharing & $\begin{array}{c}.244 \\
(.092)\end{array}$ & $\begin{array}{c}.259^{*} \\
(.092)\end{array}$ & $\begin{array}{c}-.045 \\
(.050)\end{array}$ & $\begin{array}{c}-.044 \\
(.050)\end{array}$ & $\begin{array}{r}-.010 \\
(.047)\end{array}$ & $\begin{array}{c}-.005 \\
(.047)\end{array}$ & $\begin{array}{r}-.153^{\star} \\
(.050)\end{array}$ & $\begin{array}{r}-.143^{*} \\
(.050)\end{array}$ \\
\hline Foreign aid (\%GDP) & $\begin{array}{c}.002 \\
(.003)\end{array}$ & $\begin{array}{c}.002 \\
(.003)\end{array}$ & $\begin{array}{r}-.000 \\
(.001)\end{array}$ & $\begin{array}{r}-.000 \\
(.001)\end{array}$ & $\begin{array}{c}-.001 \\
(.001)\end{array}$ & $\begin{array}{c}-.001 \\
(.001)\end{array}$ & $\begin{array}{r}-.000 \\
(.001)\end{array}$ & $\begin{array}{r}-.000 \\
(.001)\end{array}$ \\
\hline Resource rents (\%GDP) & $\begin{array}{c}-.002 \\
(.003)\end{array}$ & $\begin{array}{c}-.001 \\
(.003)\end{array}$ & $\begin{array}{r}-.004^{\star} \\
(.001)\end{array}$ & $\begin{array}{r}-.004^{\star} \\
(.001)\end{array}$ & $\begin{array}{r}-.006^{*} \\
(.001)\end{array}$ & $\begin{array}{r}-.006^{*} \\
(.001)\end{array}$ & $\begin{array}{r}-.005^{*} \\
(.001)\end{array}$ & $\begin{array}{r}-.005^{\star} \\
(.001)\end{array}$ \\
\hline Active conflict & $\begin{array}{c}-.140 \\
(.087)\end{array}$ & $\begin{array}{c}-.131 \\
(.083)\end{array}$ & $\begin{array}{c}-.048 \\
(.041)\end{array}$ & $\begin{array}{r}-.042 \\
(.041)\end{array}$ & $\begin{array}{c}-.050 \\
(.037)\end{array}$ & $\begin{array}{c}-.042 \\
(.036)\end{array}$ & $\begin{array}{r}-.101^{*} \\
(.047)\end{array}$ & $\begin{array}{r}-.090^{*} \\
(.043)\end{array}$ \\
\hline Female representation $\times$ democracy & & $\begin{array}{c}.003^{*} \\
(.001)\end{array}$ & & $\begin{array}{c}.000 \\
(.000)\end{array}$ & & $\begin{array}{c}.001^{*} \\
(.000)\end{array}$ & & $\begin{array}{c}.001^{\star} \\
(.000)\end{array}$ \\
\hline Wald $X^{2}$ & 66.87 & 93.20 & 294.68 & 339.32 & 271.57 & 295.88 & 96.23 & 109.22 \\
\hline$R^{2}$ & .22 & .25 & .54 & .54 & .51 & .52 & .39 & .41 \\
\hline$N$ & 427 & 427 & 463 & 463 & 463 & 463 & 463 & 463 \\
\hline
\end{tabular}

Note. The table presents coefficients and standard errors (in parentheses) from Prais-Winsten regression models with AR1 corrections.

${ }^{*} p \leq .05$ (one-tailed test).

that observers - including civil society organizations, business leaders, and the general public_-perceive such legislatures as superior in these areas.

\section{Female representation and peace durability}

Having established the relationship between female representation, spending, and governance outcomes, we turn to an empirical test of our primary argument. According to our hypotheses, we expect that increasing Female Representation rates will increase peace durability following conflicts terminated via negotiated settlement. ${ }^{10}$ We empirically examine the impact of this variable - as well as the impact of

10. Substituting the average female representation rate of the first five post-conflict years, which helps account for the growth of female representation overtime, yields similar results (see the appendix). the outcome variables examined in table 2 - on the durability of peace. We lag the Female Representation variable for one period in all models to account for the likely time lag between changes in the composition of government and changes in public attitudes or government spending decisions that may shape the odds of conflict.

In our analyses, we rely on the same sample defined above and utilize many of the same control variables, including Democracy, Population, Conflict Duration, Active Conflict, and Power Sharing. However, we include several additional predictors demonstrated by previous studies to influence peace durability following civil conflict. We control for Territorial Conflict using the indicator included in the UCDP data sets. We include the variable Resource Distribution, which is a binary indicator accounting for whether the conflict focused on a disagreement over the distribution of natural resources or natural resource-derived revenues (Rustad and 
Binningsbø 2012). We also include the variable UN Peacekeepers to account for the presence of a United Nations peacekeeping force (United Nations 2016a). Other studies noting a relationship between female representation and violence suggest that the rate of female representation may simply reflect norms of greater societal gender equality within the state, which may in turn influence a state's risk of involvement in conflict (Melander 2005). We therefore account for gender equality by including Secondary Education Ratio, which serves as a proxy for societal gender equality (World Bank 2015). ${ }^{11}$

Our argument focuses on the impact of female representation on the duration of time until war resumes (peace failure). To assess this relationship, we rely on conventional Cox Proportional Hazard (CPH) models using time (in days) until the resumption of conflict or until an observation is censored (exits the data set) as the outcome. While a number of parametric and nonparametric estimation options are available, we select a CPH model because it is more flexible than parametric approaches and does not require us to make assumptions about the baseline hazard. We report the results from the $\mathrm{CPH}$ models in table $3 .^{12}$ Rather than report hazard rates, we report coefficients for each variable. Positive values suggest that a given predictor increases the risk of conflict recurrence, while negative values reduce this risk.

Model 9 represents a baseline model evaluating the overall influence of Female Representation on conflict recurrence. The results from this model suggest that the proportion of female legislators has a negative and statistically significant influence on the risk of peace failure. In other words, increasing female representation increases the expected duration of peace following negotiated settlements. Model 10 introduces the control for Secondary Education Ratio. Despite accounting for this variable, the relationship between Female Representation and peace durability still obtains, providing support for our first hypothesis. This result improves our confidence that we are not simply observing a spurious relationship driven by societal gender norms: states whose legislatures include larger numbers of female members are more likely to enjoy longer periods of post-conflict peace than those with fewer female members.

Model 11 introduces the Female Representation $\times$ Democracy interaction term. The results indicate that the relation-

11. As robustness checks, we also control for other factors that may influence the number of women in a legislature and potentially the risk of conflict recurrence. Controls for legislative dominance by a left-oriented party and the presence of gender quotas do not change the results (see the appendix).

12. Standard diagnostics reveal no significant violations of the proportional hazard assumption. ship between female representation and peace durability is conditioned by the presence of more democratic political institutions. In order to examine the effects of this interaction on peace durability, we present the linear predictions in figure 1. The figure indicates that the suppressive effect of women's representation on the risk of conflict recurrence increases as a state's political institutions become more democratic. Moreover, the effect only appears to be significant (fully below the zero line) once a state's political institutions become at least modestly democratic (e.g., Polity $2=3$ ).

These results provide strong support for our hypotheses: the durability of post-conflict peace following a negotiated settlement increases as female representation increases, particularly in democratic states. However, we also argue that this relationship is driven primarily by the impact that increasing female representation exerts on perceptions of governance and on spending priorities. This proposition presupposes that these factors exert an independent influence on the longevity of post-conflict peace. While previous studies have demonstrated these relationships, we examine the influence of our proxy measures for these factors on the duration of postconflict peace in models 12-15. Model 12 includes the variable Spending Ratio, which is both negative and statistically significant. This suggests that states devoting larger proportions of annual expenditures to social welfare relative to the military enjoy longer periods of post-conflict peace. Our proxies for perceived good governance are negatively associated with conflict recurrence. While Effectiveness and Corruption Control achieve statistical significance, Accountability fails to do so.

Overall, and consistent with previous studies (Fearon 2011; Hegre and Nygärd 2015; Walter 2014, 1258), these results imply that as perceptions of good governance increase, the risk of conflict recurrence declines. ${ }^{13}$ Moreover, consistent with our argument, the inclusion of these indicators generally weakens the relationship between Female Representation and conflict recurrence. Specifically, we asserted that the impact of female representation on peace durability largely works by influencing spending priorities and shaping public perceptions of good governance and elite credibility in postconflict states, and these results support that assertion.

We plot the survival curves from model 11 in figure 2 . The figure shows the estimated proportion of cases with the specified characteristics that survive (remain at peace) until a given time point. We illustrate the effect of legislative gender

13. The lack of a significant relationship between the accountability measure and conflict risk is consistent with Fearon (2011). These studies also find that institutional measures of good governance reduce conflict risk; robustness checks using these measures yield similar results to our primary findings (see the appendix). 
Table 3. Determinants of Post-conflict Peace Durability

\begin{tabular}{|c|c|c|c|c|c|c|c|}
\hline & Model 9 & Model 10 & Model 11 & Model 12 & Model 13 & Model 14 & Model 15 \\
\hline Female representation $(t-1)$ & $\begin{array}{r}-.060^{*} \\
(.028)\end{array}$ & $\begin{array}{r}-.065^{\star} \\
(.027)\end{array}$ & $\begin{array}{r}-.016 \\
(.032)\end{array}$ & $\begin{array}{c}-.062 \\
(.049)\end{array}$ & $\begin{array}{r}-.062 \\
(.041)\end{array}$ & $\begin{array}{c}-.053 \\
(.042)\end{array}$ & $\begin{array}{c}-.057 \\
(.040)\end{array}$ \\
\hline Democracy & $\begin{array}{c}-.000 \\
(.040)\end{array}$ & $\begin{array}{r}-.025 \\
(.052)\end{array}$ & $\begin{array}{c}.075 \\
(.073)\end{array}$ & $\begin{array}{c}.042 \\
(.100)\end{array}$ & $\begin{array}{r}-.002 \\
(.102)\end{array}$ & $\begin{array}{c}-.040 \\
(.059)\end{array}$ & $\begin{array}{c}-.046 \\
(.060)\end{array}$ \\
\hline Distribution & $\begin{array}{c}.501 \\
(.440)\end{array}$ & $\begin{array}{c}.523 \\
(.492)\end{array}$ & $\begin{array}{c}.451 \\
(.481)\end{array}$ & $\begin{array}{c}.776^{*} \\
(.471)\end{array}$ & $\begin{array}{c}.694^{*} \\
(.398)\end{array}$ & $\begin{array}{c}.657^{*} \\
(.400)\end{array}$ & $\begin{array}{c}.557 \\
(.382)\end{array}$ \\
\hline $\begin{array}{l}\text { Territorial } \\
\text { Conflict }\end{array}$ & $\begin{array}{r}-.693 \\
(.600)\end{array}$ & $\begin{array}{r}-.667 \\
(.687)\end{array}$ & $\begin{array}{c}-.723 \\
(.707)\end{array}$ & $\begin{array}{c}-1.439 \\
(1.173)\end{array}$ & $\begin{array}{r}-1.558 \\
(.970)\end{array}$ & $\begin{array}{r}-1.588^{*} \\
(.954)\end{array}$ & $\begin{array}{r}-1.660^{*} \\
(.917)\end{array}$ \\
\hline Population (natural log) & $\begin{array}{c}.057 \\
(.132)\end{array}$ & $\begin{array}{c}.067 \\
(.126)\end{array}$ & $\begin{array}{c}.093 \\
(.126)\end{array}$ & $\begin{array}{c}.285^{\star} \\
(.161)\end{array}$ & $\begin{array}{c}.246 \\
(.161)\end{array}$ & $\begin{array}{c}.328^{*} \\
(.163)\end{array}$ & $\begin{array}{l}.261^{*} \\
(.148)\end{array}$ \\
\hline UN peacekeepers & $\begin{array}{c}-.131 \\
(.480)\end{array}$ & $\begin{array}{l}.241 \\
(.447)\end{array}$ & $\begin{array}{l}.318 \\
(.461)\end{array}$ & $\begin{array}{l}.182 \\
(.599)\end{array}$ & $\begin{array}{c}-.915 \\
(.918)\end{array}$ & $\begin{array}{c}-.892 \\
(.739)\end{array}$ & $\begin{array}{c}-.690 \\
(.732)\end{array}$ \\
\hline Power sharing & $\begin{array}{c}-.308 \\
(.467)\end{array}$ & $\begin{array}{c}-.189 \\
(.491)\end{array}$ & $\begin{array}{c}-.325 \\
(.495)\end{array}$ & $\begin{array}{c}.117 \\
(.588)\end{array}$ & $\begin{array}{c}.341 \\
(.694)\end{array}$ & $\begin{array}{c}.278 \\
(.624)\end{array}$ & $\begin{array}{c}.185 \\
(.590)\end{array}$ \\
\hline Conflict duration (natural log) & $\begin{array}{r}-.280^{\star} \\
(.115)\end{array}$ & $\begin{array}{r}-.315^{\star} \\
(.130)\end{array}$ & $\begin{array}{r}-.359^{*} \\
(.132)\end{array}$ & $\begin{array}{c}-.336 \\
(.212)\end{array}$ & $\begin{array}{r}-.434^{*} \\
(.217)\end{array}$ & $\begin{array}{r}-.510^{*} \\
(.238)\end{array}$ & $\begin{array}{r}-.476^{\star} \\
(.218)\end{array}$ \\
\hline Active conflict & $\begin{array}{c}.878 \\
(.585)\end{array}$ & $\begin{array}{l}1.141^{\star} \\
(.628)\end{array}$ & $\begin{array}{c}.893 \\
(.578)\end{array}$ & $\begin{array}{l}-.284 \\
(1.045)\end{array}$ & $\begin{array}{l}1.459^{*} \\
(.761)\end{array}$ & $\begin{array}{l}1.453^{*} \\
(.729)\end{array}$ & $\begin{array}{l}1.262^{\star} \\
(.746)\end{array}$ \\
\hline $\begin{array}{l}\text { Secondary } \\
\text { Education ratio }\end{array}$ & & $\begin{array}{l}.003 \\
(.012)\end{array}$ & $\begin{array}{c}.004 \\
(.012)\end{array}$ & $\begin{array}{r}-.025 \\
(.017)\end{array}$ & $\begin{array}{r}-.013 \\
(.016)\end{array}$ & $\begin{array}{r}-.002 \\
(.016)\end{array}$ & $\begin{array}{r}-.009 \\
(.016)\end{array}$ \\
\hline Female representation $\times$ democracy & & & $\begin{array}{r}-.013^{*} \\
(.006)\end{array}$ & & & & \\
\hline Spending ratio & & & & $\begin{array}{r}-.847^{*} \\
(.481)\end{array}$ & & & \\
\hline Accountability & & & & & $\begin{array}{r}-.779 \\
(.664)\end{array}$ & & \\
\hline Effectiveness & & & & & & $\begin{array}{r}-1.204^{\star} \\
(.443)\end{array}$ & \\
\hline $\begin{array}{l}\text { Corruption } \\
\text { Control }\end{array}$ & & & & & & & $\begin{array}{r}-.854^{*} \\
(.450)\end{array}$ \\
\hline Wald $X^{2}$ & 16.14 & 19.28 & 26.10 & 31.43 & 42.42 & 41.80 & 45.16 \\
\hline$N$ & 737 & 675 & 675 & 442 & 483 & 483 & 483 \\
\hline
\end{tabular}

Note. The table presents coefficients and standard errors (in parentheses) from Cox Proportional Hazard models. Standard errors are clustered on country in all models.

${ }^{\star} p \leq .05$ (one-tailed test).

diversity by showing the survival rates for the mean value of Female Representation in the sample $(10.5 \%)$ as well as one standard deviation above (18.5\%) and below (2.5\%) the mean in both democracies (left panel) and nondemocracies (right panel). ${ }^{14}$ The figure highlights the strong positive influence of female representation on peace durability following a negotiated settlement among states with more democratic political institutions. While there is little variation in the influence of

14. Survival curves are based on Polity2 scores of 6 for democracy and 0 for nondemocracy. this variable in the hypothetical nondemocratic state illustrated in the right panel, it is clear that higher rates of Female Representation substantially improve the survival rate among modestly democratic states. For instance, at 10 years postconflict, approximately $85 \%$ of democratic states with a Female Representation rate one standard deviation above the sample mean survive without experiencing conflict relapse, while only $68 \%$ of autocratic states with the same Female Representation rate survive to that point. At the mean value of Female Representation, roughly $72 \%$ of democratic cases and only $60 \%$ of autocratic cases survive until the 10 year mark. And at low levels of female representation, only around $45 \%$ 


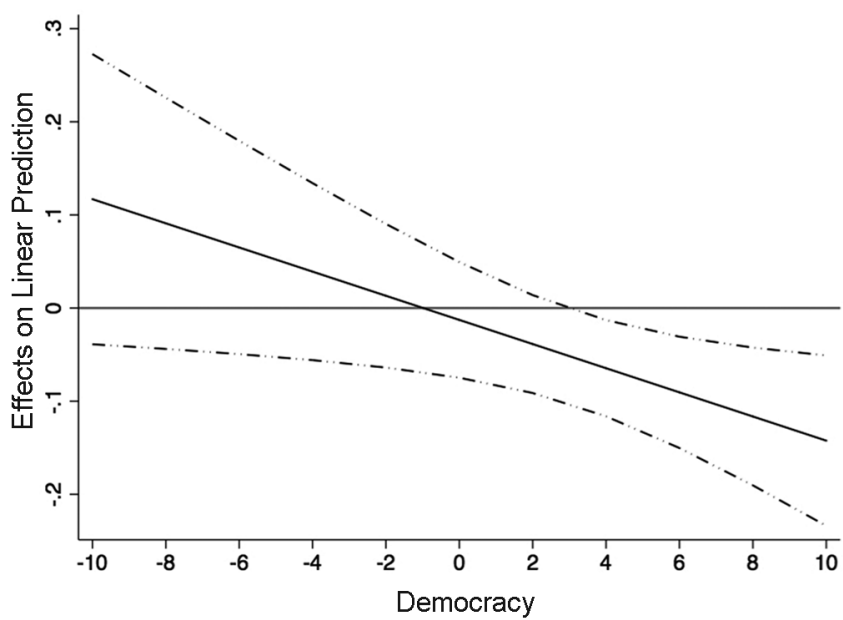

Figure 1. Conditional influence of female representation on conflict recurrence. Figure 1 shows the impact of a unit change in Female Representation on the risk of conflict recurrence over the range of the Democracy indicator based on linear predictions derived from model 11.

of democratic cases and $58 \%$ of autocratic cases survive. The difference between the effects of female representation in the context of democratic versus nondemocratic states is consistent with our expectations. The greater independence and authority of legislatures in more democratic states allow the representatives in those institutions to exert comparatively greater influence over policy outcomes compared to their counterparts in more autocratic states. Consequently, we note that very low rates of female representation in more democratic states appear to jeopardize peace, while greater female representation tends to make post-conflict peace more durable.

With respect to the control variables, we note in multiple specifications that Conflict Duration is negative and significant. This suggests that longer-and presumably more costly - conflicts are less likely to recur, as are those in countries emerging from territorial conflict. In contrast, another active conflict negatively affects peace durability, while the presence of UN peacekeepers often exerts a negative but inconsistent effect. Somewhat surprisingly, democracy appears unrelated to peace duration except when interacted with female representation. Given the results for the Effectiveness measure, this suggests that perceptions of democratic governance may be more important for preserving post-conflict peace than the institutions themselves.

Finally, it is plausible that the variable Female Representation is systematically correlated with unobservable factors related to the time since the previous conflict, thus biasing our results. To account for this possibility, we re-analyze our model using an instrumental variables approach. Specifically, we employ an IV probit model with controls for temporal depen-
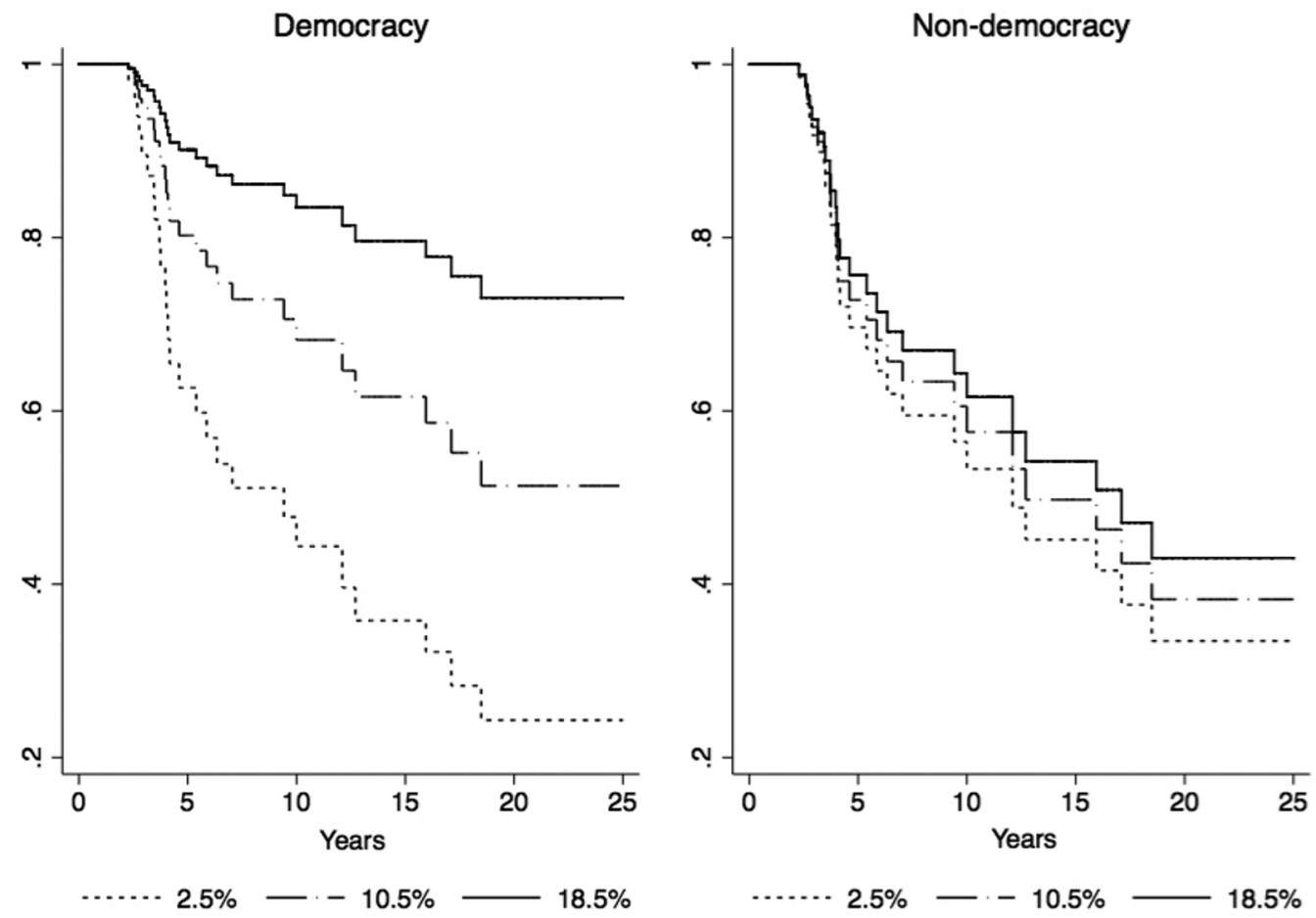

Figure 2. Survival curves from Cox Proportional Hazard models. The figure demonstrates the estimated survival rates for hypothetical states in which the conflict terminated in a peace agreement with Female Representative set at the sample mean, and one standard deviation above and below the sample mean for a democratic state (left panel) and nondemocratic state (right panel). Estimates are derived from model 11. 
dence, including both the one-year lag of the regional average of female representation and presence of nationally legislated gender quotas as our exogenous instruments. The results, discussed in the appendix (available online), are robust to this approach.

\section{CONCLUSION}

The arguments presented above posited that negotiated settlements are more durable in states with more genderinclusive political leadership. We argue that this occurs because, compared to other forms of conflict termination, negotiated settlements create more new opportunities for women's incorporation into positions of political leadership and the increase in female representation provides distinct prospects for breaking the conflict trap. Most important, we argue that increases in the rate of female representation reduce the risk of conflict occurrence by implementing policies that continue to address the conditions that drove the initial conflict and by improving perceptions of trust and credibility among political elites. We find strong empirical support for both our general argument regarding the relationship between female representation rates and peace durability, as well as the mechanisms that we believe drive this relationship: the influence of women's representation on spending priorities and perceptions of good governance. We also find that these relationships are particularly strong in democratic states, which we have argued results from the greater authority and influence exercised by legislatures in states with more democratic political institutions.

There is no guarantee that including more women will necessarily lead to these outcomes. Women's abilities to signal trust and credibility, their specific policy preferences, and their ability to implement these policies likely vary according to political and social contexts. Moreover, our argument focuses on the average attitudes and attributes of women that have been highlighted in previous literature, and our results reflect the average effect of the inclusion of such women in legislatures. Thus, an interesting question with respect to greater inclusivity as a mechanism for altering spending priorities and public perceptions is whether all women or all minority groups necessarily exert the same effect on peace durability. Distinct effects may result if different groups of women within a legislature hold competing preferences or if women's presence in decision-making roles is perceived as contrary to traditional gender stereotypes and roles, potentially producing a backlash against their inclusion and the policies they pursue. Additionally, although we have focused our attention on how the inclusion of women can lead to greater credibility among post-conflict bargaining partners, a complementary logic may extend to the inclusion of other "out-groups." That is, similar to the logic we put forth, incorporating other previously marginalized groups may improve perceptions of governance quality and result in the creation of policies that reduce the risk of war recurrence. Alternatively, however, the inclusion of these groups may provoke a contrary reaction that undermines peace. Such issues should be addressed more directly in future studies.

Finally, our study points to two important policy applications. First, we highlight the potential agency of women within the post-conflict political process. In contrast to studies that focus on gender norms or hierarchies as a causal explanation for peace, our argument and analysis place the roles of women at the forefront of policy making. While underlying gender norms likely exert a strong influence on the overall propensity for violence within a society, norms are notoriously sticky and evolve slowly over time. Thus, norms alone are unlikely to strongly influence the propensity for a state emerging from civil conflict to relapse into violence. However, conflict termination - particularly via negotiated settlementpresents a wealth of new opportunities for women to become involved in political and policy-making processes. Thus, women's formal political representation in these cases rapidly outpaces changes in societal norms. Our results suggest that this increase in female representation - rather than just underlying norms - influences the likelihood of conflict recurrence. Accordingly, our results highlight the important role that the inclusion of women in political processes plays in helping to resolve the conflict trap and secure more durable peace. From a policy standpoint, our results support advocacy for affirmative action policies that encourage or include more women in political decision-making bodies in post-conflict states.

Second, in line with previous studies (Taydas and Peksen 2012; Thyne 2006), we demonstrate the importance of social spending to prevent conflict recurrence. However, we also note that many post-conflict states appear unable or unwilling to engage in such spending despite the demonstrated benefits to achieving long-term peace. Furthermore, such spending need not occur exclusively when women are elected to office: certainly men can prioritize social welfare spending, too. Consequently, from a policy standpoint, our results broadly support government interventions that invest in and improve social welfare programs in post-conflict states.

\section{ACKNOWLEDGMENTS}

We would like to thank Tavishi Bhasin, Miki Kittilson, Vanessa Lefler, Tracy Osborn, and our anonymous reviewers for their helpful comments and suggestions. 


\section{REFERENCES}

Anderlini, Sanam. 2007. Women Building Peace: What They Do and Why It Matters. Boulder, CO: Lynne Reinner.

Anderson, Miriam J., and Liam Swiss. 2014. "Peace Accords and the Adoption of Electoral Quotas for Women in the Developing World, 1990-2006." Politics and Gender 10 (1): 33-61.

Azam, Jean-Paul. 2001. "The Redistributive State and Conflicts in Africa." Journal of Peace Research 38 (4): 429-44.

Barnes, Tiffany, and Emily Beaulieu. 2014. "Gender Stereotypes and Corruption: How Candidates Affect Perceptions of Election Fraud.” Politics and Gender 10 (3): 365-91.

Bolzendahl, Catherine, and Clem Brooks. 2007. "Women's Political Representation and Welfare State Spending in 12 Capitalist Democracies." Social Forces 85 (4): 1509-34.

Brooks, Deborah, and Benjamin Valentino. 2011. "A War of One's Own: Understanding the Gender Gap in Support for War." Public Opinion Quarterly 75 (2): 270-86.

Bush, Sarah Sunn. 2011. "International Politics and the Spread of Quotas for Women in Legislatures.” International Organization 65 (1): 103-37.

Cammett, Melani, and Edmund Malesky. 2012. "Power Sharing in Post conflict Societies: Implications for Peace and Governance." Journal of Conflict Resolution 56 (6): 982-1016.

Caprioli, Mary. 2005. "Primed for Violence: The Role of Gender Inequality in Predicting Internal Conflict.” International Studies Quarterly 49 (2): 161-78.

Caprioli, Mary, Rebecca Nielsen and Valerie Hudson. 2010. "Women after Conflict.” In J. Joseph Hewitt, Jonathan Wilkenfeld, and Ted Robert Gurr, eds., Peace and Conflict, 2010. Boulder, CO: Paradigm, 91-102.

Carroll, Susan. 2001. "Representing Women: Women Legislators as Agents of Policy Related Change.” In Susan Carroll, ed., The Impact of Women in Office. Bloomington: Indiana University Press.

Collier, Paul, V. L. Elliott, Håvard Hegre, Anke Hoeffler, Marta ReynalQuerol, and Nicholas Sambanis. 2003. Breaking the Conflict Trap: Civil War and Development Policy. Oxford: Oxford University Press.

Collier, Paul, and Anke Hoeffler. 2006. "Military Expenditure in Postconflict Societies.” Economics of Governance 7 (1): 89-107.

Conover, Pamela Johnston, and Virginia Sapiro. 1993. "Gender, Gender Consciousness and War.” American Journal of Political Science 37 (4): 1079-99.

Crowley, Jocelyn Elise. 2004. "When Tokens Matter." Legislative Studies Quarterly 29 (1): 109-36.

Demeritt, Jacqueline H. R., Angela D. Nichols, and Eliza G. Kelly. 2015 "Female Participation and Civil War Relapse." Civil Wars 16 (3): 346-68.

Ellerby, Kara. 2013. “(En)gendered Security? The Complexities of Women's Inclusion in the Peace Process.” International Interactions 39 (4): 435-60.

Erickson, Lynda. 1997. "Might More Women Make a Difference? Gender, Party and Ideology among Canada's Parliamentary Candidates.” Canadian Journal of Political Science 30 (4): 663-88.

Fearon, James. 2011. "Governance and Civil War Onset." World Development Report, 2011. World Bank. https://openknowledge.worldbank.org /bitstream/handle/10986/9123/WDR2011_0002.pdf?sequence = 2 (accessed April 25, 2017).

Gandhi, Jennifer. 2008. Political Institutions under Dictatorship. New York: Cambridge University Press.

Ghobarah, Hazem Adam, Paul Huth, and Bruce Russet. 2004. "The Postwar Public Health Effects of Civil Conflict.” Social Science and Medicine 59 (4): 869-84

Gleditsch, Kristian Skrede. 2002. "Expanded Trade and GDP Data.” Journal of Conflict Resolution 46 (5): 712-24.

Gleditsch, Nils Petter, Peter Wallensteen, Mikael Eriksson, Margareta Sollenberg, and Håvard Strand. 2002. "Armed Conflict 1946-2001: A New Dataset.” Journal of Peace Research 39 (5): 615-37.
Govender, Pregs. 2002. "Farewell and Thank You: Farewell Speech by ANC MP Pregs Govender,” May 30. http://www.anc.org.za/content/farewell -and-thank-you-farewell-speech-anc-mp-pregs-govender (accessed August 2, 2016).

Hartzell, Caroline, and Matthew Hoddie. 2007. Crafting Peace: PowerSharing Institutions and the Negotiated Settlement of Civil Wars. University Park: Pennsylvania State University Press.

Hartzell, Caroline, Matthew Hoddie, and Donald Rothchild. 2001. "Stabilizing the Peace after Civil War: An Investigation of Some Key Variables." International Organization 55 (1): 183-208.

Hegre, Håvard, and Håvard Nygärd. 2015. "Governance and Conflict Relapse.” Journal of Conflict Resolution 59 (6): 984-1016.

Hicks, Daniel, Joan Hicks, and Beatriz Maldonado. 2015. “Are Female Politicians More Responsive to International Crises?” Applied Economic Letters 22 (6): 493-98.

Hudson, Valerie, Mary Caprioli, Bonnie Balli-Spanvill, Rose McDermott, and Chad Emmett. 2009. "The Heart of the Matter: The Security of Women and the Security of States." International Security 33 (3): 7-45.

Hughes, Melanie M. 2009. "Armed Conflict, International Linkages, and Women's Parliamentary Representation in Developing Nations.” Social Problems 56 (1): 174-204.

Hughes, Melanie M., and Aili Mari Tripp. 2015. "Civil War and Trajectories of Change in Women's Political Representation in Africa, 1985-2010.” Social Forces 93 (4): 1513-40.

Iqbal, Zaryab. 2010. War and the Health of Nations. Stanford, CA: Stanford University Press.

Kaufmann, Daniel, Aart Kraay, and Massimo Mastruzzi. 2011. "The Worldwide Governance Indicators: Methodology and Analytical Issues.” Hague Journal of International Law 3 (2): 220-46.

Kittilson, Miki Caul. 2008. "Representing Women: The Adoption of Family Leave in a Comparative Perspective." Journal of Politics 70 (2):323-34.

Koch, Michael, and Sarah Fulton. 2011. "In the Defense of Women: Gender, Office Holding, and National Security Policy in Established Democracies." Journal of Politics 73 (1): 1-16.

Kreutz, Joakim. 2010. "How and When Armed Conflicts End: Introducing the UCDP Conflict Termination Dataset.” Journal of Peace Research 47 (2): 243-50.

Krook, Mona Lena, and Jacqui True. 2012. "Rethinking the Life Cycles of International Norms: The United Nations and the Global Promotion of Gender Equality." European Journal of International Relations 18 (1): 103-27.

Lawless, Jennifer. 2004. "Politics of Presence? Congresswomen and Symbolic Representation.” Political Research Quarterly 57 (1): 81-99.

Lijphart, Arend. 1987. "Bicameralism: Canadian Senate Reform in Comparative Perspective." In Herman Bakvis and William M. Chandler, eds., Federalism and the Role of the State. Toronto, ON: University of Toronto Press, 101-12.

Lu, Kelan, and Marijke Breuning. 2014. "Gender and Generosity: Does Women's Representation Affect Development Cooperation?” Politics, Groups and Identities 2 (3): 313-30.

Mansbridge, Jane. 1999. "Should Blacks Represent Blacks and Women Represent Women? A Contingent 'Yes.'” Journal of Politics 61 (3): 628-57.

Marshall, Monty G., Keith Jaggers, and Ted Robert Gurr. 2011. Polity IV Project: Political Regime Characteristics and Transitions, 1800-2010, Dataset Users' Manual. Vienna, VA: Center for Systemic Peace.

Mattes, Michaela, and Burcu Savun. 2009. "Fostering Peace after Civil War: Commitment Problems and Agreement Design.” International Studies Quarterly 53 (3): 737-59.

McDermott, Monika L. 1998. "Race and Gender Cues in Low-Information Elections.” Political Research Quarterly 51 (4): 895-918.

McDermott, Rose, and Jonathan Cowden. 2002. "The Effects of Uncertainty and Sex in a Crisis Simulation Game." International Interactions 27 (4): 353-80. 
McGrew, Laura, Kate Frieson, and Sambath Chan. 2004. Good Governance from the Ground Up: Women's Roles in Post-conflict Cambodia. Report, Women Waging Peace Policy Commission.

Melander, Erik. 2005. "Gender Equality and Intrastate Conflict." International Studies Quarterly 49 (4): 695-714.

Mukherjee, Bumba. 2006. "Why Political Power-Sharing Agreements Lead to Enduring Peaceful Resolution of Some Civil Wars, but Not Others?" International Studies Quarterly 50 (2): 479-504.

Murshed, Mansoob S. 2002. "Conflict, Civil War, and Underdevelopment: An Introduction." Journal of Peace Research 39 (4): 387-93.

Paffenholz, Thania. 2014. "Civil Society and Peace Negotiations: Beyond the Inclusion-Exclusion Dichotomy." Negotiation Journal 30 (1): 6991.

Paxton, Pamela, Jennifer Green, and Melanie Hughes. 2008. Women in Parliament, 1945-2003: Cross-National Dataset. ICPSR24340-v1. Ann Arbor, MI: Inter-university Consortium for Political and Social Research [distributor], December 22, 2008. http://doi.org/10.3886/ICPSR24340.v1 (accessed April 25, 2017).

Paxton, Pamela, Melanie M. Hughes, and Jennifer Green. 2006. “The International Women's Movement and Women's Political Representation, 1893-2003.” American Sociological Review 71 (6): 898-920.

Pew Research Center. 2015. "Women and Leadership: Public Says Women Are Equally Qualified, but Barriers Persist.” Pew Research Center, Washington, DC (January).

Reiter, Dan. 2015. "The Positivist Study of Gender and International Relations." Journal of Conflict Resolution 59 (7): 1301-26.

Ruddick, Sara. 1995. Maternal Thinking: Toward a Politics of Peace. Boston: Beacon.

Rudman, Laurie A., and Stephanie A. Goodwin. 2004. "Gender Differences in Automatic In-Group Bias: Why Do Women Like Women More than Men Like Men?" Journal of Personality and Social Psychology 87 (4): 494-509.
Rustad, Siri, and Helga Binningsbø. 2012. “A Price Worth Fighting For? Natural Resources and Conflict Recurrence.” Journal of Peace Research 39 (4): 531-46.

Schwindt-Bayer, Leslie. 2010. Political Power and Women's Representation in Latin America. New York: Oxford University Press.

Sjoberg, Laura, and Caron Gentry. 2007. Mothers, Monsters, Whores: Women's Violence in Global Politics. New York: Zed Books.

Swiss, Liam, Kathleen Fallon, and Giovani Burgos. 2012. "Does Critical Mass Matter? Women's Political Representation and Child Health in Developing Countries.” Social Forces 91 (2): 531-57.

Taydas, Zeynep, and Dursen Peksen. 2012. "Can States Buy Peace? Social Welfare Spending and Civil Conflicts." Journal of Peace Research 49 (2): 273-87.

Thyne, Clayton. 2006. "ABCs, 123s, and the Golden Rule: The Pacifying Effect of Education on Civil War, 1980-1999." International Studies Quarterly 50 (4): 733-54.

Toft, Monica Duffy. 2009. Securing the Peace: The Durable Settlement of Civil Wars. Princeton, NJ: Princeton University Press.

Treisman, Daniel. 2007. "What Have We Learned about the Causes of Corruption from Ten Years of Cross-National Empirical Research?" Annual Review of Political Science 10:211-44.

Tripp, Aili Marie. 2015. Women and Power in Post-conflict Africa. New York: Cambridge University Press.

United Nations. 2016a. United Nations Peacekeeping. http://www.un.org /en/peacekeeping/ (accessed April 25, 2017).

United Nations. 2016b. UNdata. http://data.un.org/Data.aspx?q=health + expenditure\&d=WHO\&f=MEASURE_CODE\%3aWHS7_143 http:// data.un.org/Explorer.aspx?d = WHO (accessed April 25, 2017).

Walter, Barbara. 2014. "Why Bad Governance Leads to Repeat Civil War." Journal of Conflict Resolution 59 (7): 1242-72.

World Bank. 2015. World Development Indicators. http://data.worldbank .org/indicator. 